\title{
PENGARUH BUBUK DAUN KENIKIR (Cosmos caudatus) TERHADAP KADAR MALONDIALDEHYDE PLASMA TIKUS WISTAR DIABETES DIINDUKSI STREPTOZOTOCIN
}

\author{
Fredian Suhardinata, Etisa Adi Murbawani*)
}

Program Studi Ilmu Gizi Fakultas Kedokteran Universitas Diponegoro

Jl.Dr.Sutomo No.18, Semarang, Telp (024) 8453708, Email : gizifk@undip.ac.id

\begin{abstract}
Background: Diabetic vascular complication occur because of the formation of free radical rised and resulted in oxidative stress. The most stable level of oxidative stress is malondialdehyde (MDA). Oxidative stress can maintained with high consumption of non-ezymatic antioxidant. "Kenikir" leaf contained potential non-ezymatic antioxidant, class of flavonoid that is quercetin. The aim of this study is to analyze the effect of "kenikir" leaf powder on plasma malondialdehyde level in streptozotocin induced diabetic Wistar rats.

Method: This study was true experimental with post-test only randomized control group design. The subject were 21 male Wistar rats and they were divided into 3 groups, $K^{+}, P 1$, and $P 2$. All of the subject were induced by streptozotocin $65 \mathrm{mg} / \mathrm{kg}$ weight and nicotinamide $230 \mathrm{mg} / \mathrm{kg}$ weight. P1 and P2 group given a daily dose of $700 \mathrm{mg} / 200 \mathrm{~g}$ weight and 1400 mg/200g weight "kenikir" leaf powder for 21 days. Plasma MDA analyzed by 2-Thiobarbituric Acid Reactive Substance (TBARS) method. The data were analyzed by One Way Anova and Post-hoc LSD.

Result: Doses $700 \mathrm{mg}(P 1)$ and $1400 \mathrm{mg}(\mathrm{P2})$ "kenikir" leaf powder can lower plasma MDA levels in streptozotocin induced diabetic Wistar rats $(p<0,05)$. The mean value of plasma MDA levels in $K^{+}$group, P1 group, and P2 group were $7,7 \pm 0,61,6,1 \pm 0,58$, and 2,8 $\pm 0,50$. There were significant difference of mean value of plasma MDA levels between groups $(p<0,05)$.

Conclusion: "Kenikir" leaf powder with daily dose $700 \mathrm{mg} / 200 \mathrm{~g}$ weight and $1400 \mathrm{mg} / 200 \mathrm{~g}$ weight can lower plasma MDA level in streptozotocin induced diabetic wistar rats for 21 days. Dose $1400 \mathrm{mg} / 200 \mathrm{~g}$ weight more effective to lower plasma MDA level.
\end{abstract}

Keyword: "Kenikir” (Cosmos caudatus) Leaf Powder, plasma MDA, Diabetic

\begin{abstract}
ABSTRAK
Latar Belakang: Komplikasi vaskular diabetes terjadi akibat meningkatnya pembentukan radikal bebas sehingga menyebabkan stress oksidatif. Parameter tingkat stress oksidatif paling stabil adalah malondialdehyde (MDA). Stress oksidatif dapat dikendalikan dengan meningkatkan konsumsi antioksidan nonenzimatik. Daun kenikir memiliki zat antioksidan nonenzimatik potensial golongan flavonoid yaitu kuersetin. Penelitian ini bertujuan menganalisis pengaruh bubuk daun kenikir terhadap kadar malondialdehyde plasma tikus Wistar diabetes diinduksi streptozotocin. Metode: Jenis penelitian ini adalah true experimental dengan post-test only randomized control group design. Subjek penelitian yaitu 21 ekor tikus Wistar jantan dibagi menjadi 3 kelompok, $K^{+}, P 1$, dan P2. Seluruh kelompok diinduksi streptozotocin $65 \mathrm{mg} / \mathrm{kg}$ dan nicotinamide $230 \mathrm{mg} / \mathrm{kg}$, kelompok perlakuan diberi bubuk daun kenikir dosis 700 mg/200gBB/hari dan $1400 \mathrm{mg} / 200 \mathrm{gBB} /$ hari selama 21 hari. Pemeriksaan kadar MDA plasma dengan metode 2Thiobarbituric Acid Reactive Substance (TBARS). Data dianalisis menggunakan uji One Way Anova dan Post-hoc LSD.

Hasil: Dosis 700 mg (P1) dan 1400 mg (P2) bubuk daun kenikir mampu menurunkan kadar MDA plasma tikus Wistar diabetes diinduksi streptozotocin ( $1<0,05)$. Rerata kadar MDA plasma kelompok kontrol positif sebesar 7,7 $\pm 0,61$,

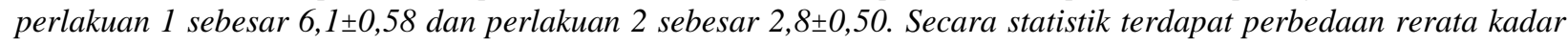
MDA plasma antar kelompok ( $p<0,05)$.

Simpulan: Bubuk daun kenikir dosis $700 \mathrm{mg} / 200 \mathrm{gBB} / \mathrm{hari}$ dan $1400 \mathrm{mg} / 200 \mathrm{gBB} / \mathrm{hari}$ selama 21 hari mampu menurunkan kadar MDA plasma tikus Wistar diabetes diinduksi streptozotocin. Dosis $1400 \mathrm{mg} / 200 \mathrm{gBB} / \mathrm{hari}$ bubuk daun kenikir lebih efektif menurunkan kadar MDA plasma.
\end{abstract}

Kata Kunci: Bubuk Daun Kenikir (Cosmos caudatus), MDA plasma, Diabetes

\section{PENDAHULUAN}

Berdasarkan data World Health Organization (WHO), jumlah pasien diabetes melitus (DM) diprediksi setiap tahun mengalami peningkatan. Penderita DM di dunia meningkat dari 171 juta orang (2000) menjadi 366 juta orang (2030). World Health Organization memprediksi penderita DM di Indonesia mengalami kenaikan dari 8,4 juta (2000) menjadi sekitar 21,3 juta (2030). Peningkatan tersebut disebabkan karena perubahan gaya hidup, peningkatan prevalensi obesitas, dan proses degeneratif. ${ }^{1,2}$

Hiperglikemia merupakan karakteristik pada penderita diabetes melitus (DM) yang terjadi karena kelainan sekresi insulin, kerja insulin atau keduanya. ${ }^{2}$ Kondisi hiperglikemia terjadi akibat

${ }^{*}$ Penulis Penanggungjawab 
meningkatnya kadar glukosa darah lebih dari 7 $\mathrm{mmol} / \mathrm{liter}(126 \mathrm{mg} / \mathrm{dl})$ untuk glukosa darah puasa. ${ }^{1}$ Hiperglikemia kronik pada diabetes melitus (DM) berhubungan dengan kerusakan jangka panjang, disfungsi atau kegagalan beberapa organ tubuh, terutama mata, ginjal, saraf, jantung, dan pembuluh darah. ${ }^{2,3}$

Menurut World Health Organization, DM menyebabkan morbiditas dan mortalitas yang tinggi, terutama karena komplikasi vaskularnya. Luasnya komplikasi pada DM tampaknya berkorelasi dengan konsentrasi glukosa darah sehingga glukosa berlebih diduga menjadi penyebab utama kerusakan jaringan. ${ }^{1}$ Hal tersebut dapat terjadi akibat meningkatnya pembentukan radikal bebas melalui jalur metabolisme glukosa seperti autooksidasi glukosa, metabolisme pembentukan metilglioksal, dan fosforilasi oksidatif. ${ }^{4}$

Salah satu jenis radikal bebas yang sangat reaktif adalah radikal hidroksil. Radikal hidroksil sangat toksik karena kemampuannya untuk berdifusi ke dalam membran sel yang selanjutnya bereaksi dengan membran lipid menghasilkan produk malondialdehyde

(MDA) ${ }^{5}$ Malondialdehyde merupakan hasil akhir peroksidasi lipid yang digunakan sebagai parameter tingkat stress oksidatif dan risiko komplikasi pada diabetes melitus. ${ }^{5,6}$ Modifikasi molekuler akibat stress oksidatif pada berbagai jaringan mengakibatkan ketidakseimbangan antara antioksidan protektif (endogen) dan peningkatan produksi radikal bebas yang berakhir pada kerusakan oksidatif sehingga meningkatkan risiko komplikasi pada $\mathrm{DM}^{4}{ }^{4}$ Diperlukan antioksidan eksogen (nonenzimatik) untuk meredam kerusakan oksidatif. Salah satu antioksidan yang dapat menghambat kerusakan oksidatif adalah kuersetin. ${ }^{7,8}$

Kuersetin merupakan antioksidan potensial golongan flavonoid sub kelas flavonols yang memiliki efek proteksi pada beberapa penyakit seperti kanker, penyakit kardiovaskular, arthtritis, hiperurisemia dan diabetes melitus melalui proteksi membran sel untuk menghambat stress oksidatif. ${ }^{7,8}$ Beberapa penelitian menunjukkan bahwa secara in vivo kuersetin dapat menurunkan glukosa darah, melindungi fungsi sel beta pankreas serta menurunkan angka morbiditas dan mortalitas pada tikus model komplikasi vaskular diabetes melalui penurunan kadar MDA. ${ }^{9}, 10$ Kuersetin banyak terdapat pada beberapa sayuran, salah satunya adalah daun kenikir. ${ }^{11}$

$$
\text { Daun kenikir (Cosmos caudatus) }
$$

merupakan salah satu sayuran yang sering dikonsumsi oleh masyarakat Indonesia sebagai lalapan, gudangan dan pecel. Penelitian terbaru menyatakan ekstrak Cosmos caudatus memiliki aktivitas antioksidan yang kuat sebesar $70 \%$ dan dapat digunakan sebagai penangkal radikal bebas. ${ }^{12}$ Menurut penelitian Andarwulan, daun kenikir segar mengandung total fenol 1,52 mg GAE/g dan kadar flavonoid sebesar $143 \mathrm{mg} / 100 \mathrm{~g}$ dengan kandungan flavonoid jenis kuersetin paling tinggi sebesar 51,3 $\mathrm{mg} / 100$ g. ${ }^{11}$ Penelitian lain menyebutkan daun kenikir memiliki kapasitas antioksidan yang tinggi setara dengan kapasitas antioksidan $2400 \mathrm{mg}$ asam L-askorbat acid equivalent antioxidant capacity (AEAC) per $100 \mathrm{~g}$ berat segar. ${ }^{13}$ Jenis flavonoid paling banyak dalam daun kenikir adalah kuersetin 3-O-glukosida, kuersetin pentose dan kuersetin deoksil-heksose. ${ }^{14}$

Pengolahan daun kenikir dari sayuran segar menjadi bubuk bersifat inovatif yang mempunyai prospek menjanjikan karena dalam penyajian lebih praktis, mudah dikonsumsi, tahan lebih lama dan tersedia setiap saat, serta diharapkan dapat meningkatkan konsumsi sayur yang sampai saat ini masih rendah. ${ }^{15}$ Sayur termasuk sumber antioksidan nonenzimatik (eksogen) yang dibutuhkan oleh tubuh untuk menetralisir radikal bebas. ${ }^{16}$ Bubuk daun kenikir diharapkan dapat menjadi salah satu alternatif untuk mencukupi kebutuhan antioksidan.

Penelitian ini menggunakan hewan coba berupa tikus putih jantan (Rattus norvegicus) galur Wistar. Tikus jantan dipilih karena tidak memiliki hormon esterogen yang berfungsi menjaga keseimbangan kadar glukosa darah. ${ }^{17}$ Sedangkan galur Wistar direkomendasikan untuk penelitian hewan coba diabetes karena secara genetik dapat diinduksi diabetes, memiliki karakteristik mirip manusia dari data fisiologis maupun biokimia glukosa darah. ${ }^{17,18}$ Induksi diabetes menggunakan streptozotocin (STZ), karena dapat menghambat sekresi insulin dan menyebabkan suatu keadaan yang dikenal dengan insulin-dependent diabetes mellitus. ${ }^{19}$ Penambahan induksi nicotinamide (NA) untuk mengendalikan kerusakan sel beta pankreas yang berlebihan dan memberikan proteksi sel beta pankreas hewan coba akibat induksi STZ. ${ }^{20}$

Beberapa penelitian telah membuktikan pengaruh kuersetin murni terhadap kadar MDA pada kondisi diabetes, namun belum terdapat bukti ilmiah apakah kuersetin daun kenikir juga dapat berpengaruh terhadap kadar MDA pada kondisi diabetes. Oleh karena itu, penelitian dilakukan untuk mengetahui pengaruh daun kenikir dalam bentuk bubuk terhadap kadar MDA plasma tikus wistar diabetes diinduksi streptozotocin. 


\section{METODE PENELITIAN}

Penelitian ini merupakan penelitian posttest only with randomized control group design dan termasuk ruang lingkup gizi biomedik. Penelitian dilakukan di Laboratorium Ilmu Pangan UNIKA Soegiyapranata Semarang untuk pemeriksaan kandungan kuersetin bubuk daun kenikir, sedangkan pemeliharaan hewan coba, perlakuan, pengambilan sampel dan pemeriksaan kadar MDA plasma dilakukan di Laboratorium Pusat Studi Pangan dan Gizi UGM Yogyakarta. Pelaksanaan penelitian ini telah mendapatkan persetujuan dari Komite Etik Penelitian Kesehatan Fakultas Kedokteran Universitas Diponegoro dengan terbitnya Ethical Clearance No. 471/EC/FKRSDK/2015.

Subjek penelitian ini adalah tikus jantan (Rattus norvegicus) galur Wistar yang memenuhi kriteria inklusi meliputi usia 8-12 minggu, berat badan 100-200 gram, kadar glukosa darah puasa setelah induksi streptozotocin (STZ) dan nicotinamide (NA) > $126 \mathrm{mg} / \mathrm{dL}$, dan sehat. Kriteria eksklusi meliputi tikus sakit sebelum perlakuan, mengalami perubahan perilaku (kehilangan nafsu makan dan lemas) dan mati saat perlakuan. Penelitian ini terdapat tiga kelompok, yaitu satu kelompok kontrol positif dan dua kelompok perlakuan dengan dosis bertingkat. Perhitungan jumlah sampel minimal hewan coba berdasarkan WHO adalah 5 ekor setiap kelompok, untuk mengantisipasi drop out maka jumlah sampel 7 ekor setiap kelompok sehingga jumlah sampel ketiga kelompok sebanyak 21 ekor tikus.

Variabel bebas dalam penelitian ini adalah bubuk daun kenikir. Daun kenikir merupakan bagian daun pada tanaman kenikir yang didapatkan dari Pasar Peterongan Semarang. Bubuk daun kenikir diperoleh dari daun kenikir segar yang mengalami proses pembubukan. Proses pembubukan dimulai dengan membersihkan dan mencuci daun kenikir. Setelah itu daun kenikir dikeringkan dengan oven pengering listrik dengan suhu $50{ }^{0} \mathrm{C}$. Kemudian daun kenikir kering dihaluskan menggunakan grinder lalu diayak sehingga dihasilkan bubuk daun kenikir. Selanjutnya dilakukan uji kandungan kuersetin bubuk daun kenikir melalui proses ekstraksi dan diukur menggunakan spektrodensitometer C 5930 Scanner (Shimadzu, Japan).

Variabel terikat dalam penelitian ini adalah kadar malondialdehyde (MDA) plasma tikus. Malondialdehyde (MDA) plasma merupakan hasil akhir peroksidase lipid yang didapatkan dari plasma darah. Pemeriksaan kadar MDA plasma dilakukan dengan metode 2-Thiobarbituric Acid Reactive
Substance (TBARS). Kadar MDA dihitung sebagai reaksi kuantitatif thiobarbituric acid (TBA) menggunakan spektrofotometer. Absorbansi kadar MDA dibaca pada $\lambda 532 \mathrm{~nm}$. Variabel yang dikendalikan dalam penelitian ini adalah asupan makan, berat badan, usia, galur dan aktivitas fisik tikus.

Seluruh hewan coba dilakukan adaptasi selama 3 hari. Pemberian pakan standar AD II (JAPFA Comfeed) sebanyak 15-20 g/hari serta air minum ad libitium. Selain itu, berat badan tikus juga ditimbang 3 hari sekali. Hewan coba dengan kelompok kontrol positif dan perlakuan diinduksi STZ $65 \mathrm{mg} / \mathrm{kg}$ BB tikus dan NA $230 \mathrm{mg} / \mathrm{kg} \mathrm{BB}$ tikus secara intraperitoneal dengan lama waktu menjadi diabetes 5 hari. ${ }^{17}$

Kelompok perlakuan diintervensi bubuk daun kenikir dengan dosis yang bertingkat sebesar $700 \mathrm{mg} / 200 \mathrm{gBB} /$ hari untuk perlakuan 1 dan 1400 $\mathrm{mg} / 200 \mathrm{~g} / \mathrm{hari}$ untuk perlakuan 2. Dosis tersebut berdasarkan konsumsi daun kenikir segar rata-rata per hari untuk manusia sebesar $200 \mathrm{~g}^{21}$ Dosis intervensi bubuk daun kenikir didapatkan dari konversi manusia dengan berat badan 70kg ke tikus dengan berat badan $200 \mathrm{~g}$, kemudian dilakukan konversi daun kenikir segar ke bubuk daun kenikir (Lampiran). Dosis intervensi sesuai dengan dengan penelitian mengenai uji toksisitas daun kenikir yaitu dosis optimal yang dianjurkan berkisar $100 \mathrm{mg}-$ 2000 mg. ${ }^{12,22,23}$ Pemberian bubuk daun kenikir melalui sonde dengan melarutkan bubuk daun kenikir menggunakan air sebanyak $4 \mathrm{ml}$ pada masing-masing dosis. Intervensi diberikan selama 21 hari. $^{22}$

Hari ke 3 saat aklimatisasi dilakukan pemeriksaan kadar glukosa darah puasa awal sebelum induksi STZ dan NA, kemudian pada hari ke 8 dilakukan pemeriksaan kadar glukosa darah puasa setelah induksi STZ dan NA. Pemeriksaan kadar MDA plasma tikus dilakukan setelah tikus diberikan perlakuan bubuk daun kenikir selama 21 hari (post test). Sebelum pemeriksaan, tikus dipuasakan selama 12 jam. Pengambilan darah dilakukan melalui plexus retro orbitalis pada mata. Darah yang diperoleh ditempatkan dalam blood tube berisi EDTA yang berfungsi sebagai antikoagulan, kemudian disentrifugasi untuk memisahkan bagian supernatan dan platelet. Bagian yang diambil adalah supernatan yang mengandung plasma darah. Pengukuran MDA pada plasma darah karena sebagian besar MDA pada darah terdapat di dalam plasma, selain pada serum dan jaringan. ${ }^{24}$

Data yang diperoleh dianalisis menggunakan program komputer. Data tersebut 
diuji normalitasnya menggunakan uji Shapiro-wilk. Perbedaan kadar MDA plasma pada ketiga kelompok perlakuan dianalisis menggunakan uji statistik parametrik One Way Anova jika data berdistribusi normal. Selanjutnya, untuk melihat kelompok perlakuan yang bermakna terhadap kadar
MDA plasma maka digunakan analisis Post Hoc LSD.

\section{HASIL PENELITIAN}

Uji kandungan flavonoid dan kuersetin

Hasil uji kandungan flavonoid dan kuersetin bubuk daun kenikir tersaji dalam tabel 1 .

Tabel 1. Hasil uji kandungan flavonoid dan kuersetin bubuk daun kenikir

\begin{tabular}{lc}
\hline Kandungan & $\begin{array}{c}\text { Bubuk Daun Kenikir } \\
\text { per 100g }\end{array}$ \\
\hline Total Flavonoid & $1089,79 \mathrm{mg}$ \\
Kuersetin & $390,95 \mathrm{mg}$ \\
\hline
\end{tabular}

Berdasarkan hasil uji diketahui kandungan flavonoid dan kuersetin pada masing-masing dosis intervensi bubuk daun kenikir, yaitu dosis 1 (700 $\mathrm{mg}$ ) mengandung flavonoid $7,62 \mathrm{mg}$ dan kuersetin $2,74 \mathrm{mg}$ sedangkan dosis $2(1400 \mathrm{mg})$ mengandung flavonoid 15,26 mg dan kuersetin 5,47 mg.

Berat badan subjek penelitian
Subjek penelitian adalah 21 ekor tikus Wistar jantan berusia 8-12 minggu. Penelitian meliputi pemeliharaan, induksi diabetes dan pemeriksaan kadar MDA plasma tikus dilakukan di Laboratorium Pusat Studi Pangan dan Gizi UGM. Berikut perbedaan berat badan subjek penelitian sebelum dan sesudah perlakuan ditampilkan dalam tabel 2

Tabel 2. Perbedaan berat badan subjek penelitian sebelum dan sesudah perlakuan

\begin{tabular}{l}
$\begin{array}{l}\text { Berat } \\
\text { Badan }\end{array}$ \\
\cline { 3 - 6 }
\end{tabular}

Hasil uji Wilcoxon rerata berat badan sebelum dan sesudah perlakuan pada kelompok kontrol positif menunjukkan nilai signifikansi sebesar 0,008 $(p<0,05)$ dengan penurunan berat badan sebesar 13,99\%. Sedangkan hasil uji Paired t-test rerata berat badan sebelum dan sesudah perlakuan pada kelompok perlakuan 1 dan perlakuan 2 menunjukkan nilai signifikansi sebesar $0,000 \quad(p<0,05)$ dengan kenaikan berat badan sebesar $11,87 \%$ pada perlakuan 1 dan kenaikan berat badan sebesar $11,63 \%$ pada perlakuan 2 . Hal ini menunjukkan terdapat perbedaan berat badan secara signifikan pada sebelum dan sesudah perlakuan pada masing-masing kelompok.

Uji korelasi Pearson dilakukan untuk mengetahui hubungan antara berat badan sesudah perlakuan dan kadar MDA plasma. Hasil uji korelasi Pearson menunjukkan bahwa terdapat hubungan yang bermakna antara berat badan sesudah perlakuan dengan kadar MDA plasma dengan nilai signifikansi $0,008(p<0,05)$. Kekuatan korelasi sebesar $-0,560$ menunjukkan bahwa terdapat korelasi negatif antara berat badan sesudah perlakuan dan kadar MDA plasma dengan kekuatan korelasi kategori sedang.

Perbedaan kadar MDA plasma antar kelompok Data post-test kadar MDA plasma yang didapat kemudian dianalisis normalitasnya menggunakan uji Shapiro-wilk. Hasil uji normalitas pada tiap kelompok berdistribusi normal dengan masing-masing signifikansi sebesar 0,625 kelompok kontrol positif, 0,626 kelompok perlakuan 1, 0,864 kelompok perlakuan $2(p>0,05)$. Kemudian dilakukan uji Levene untuk menguji homogenitas dan didapatkan hasil nilai signifikansi $0,842(p>0,05)$ yang menunjukkan antar kelompok 
memiliki data homogen. Berdasarkan hasil uji normalitas dan homogenitas, maka dilakuan uji parametrik One Way Anova yang ditampilkan pada tabel 3.

Tabel 3. Rerata kadar MDA plasma antar kelompok

\begin{tabular}{cccccc}
\hline $\begin{array}{c}\text { Kadar MDA } \\
\text { plasma }\end{array}$ & $\mathbf{n}$ & $\begin{array}{c}\text { Rerata } \pm \text { SD } \\
(\mathbf{n m o l} / \mathbf{m l})\end{array}$ & Min & Max & $\boldsymbol{p}$ \\
\hline $\mathrm{K}^{+}$ & 7 & $7,7 \pm 0,61$ & 6,80 & 8,41 & \\
$\mathrm{P} 1$ & 7 & $6,1 \pm 0,58$ & 5,49 & 7,10 & $0,000^{*}$ \\
$\mathrm{P} 2$ & 7 & $2,8 \pm 0,50$ & 2,08 & 3,52 & \\
\hline
\end{tabular}

Uji One Way Anova *berbeda bermakna $(p<0,05)$

Hasil analisis One Way Anova didapatkan nilai signifikansi $0,000(p<0,05)$, dapat disimpulkan bahwa terdapat perbedaan rerata kadar MDA plasma antar ketiga kelompok atau terdapat pengaruh bubuk daun kenikir terhadap kadar MDA plasma. Berdasarkan tabel 3 diketahui rerata kadar MDA plasma pada kelompok kontrol positif sebesar $7,7 \pm 0,61 \mathrm{nmol} / \mathrm{ml}$, kelompok perlakuan 1 sebesar $6,1 \pm 0,58 \mathrm{nmol} / \mathrm{ml}$ dan kelompok perlakuan 2 sebesar $2,8 \pm 0,50 \mathrm{nmol} / \mathrm{ml}$.

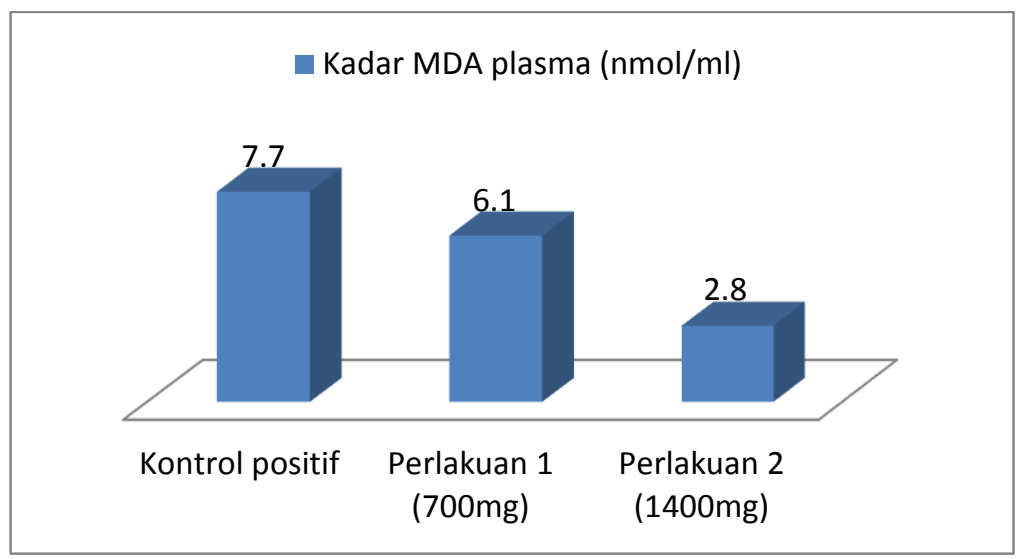

Gambar 1. Diagram rerata kadar MDA plasma masing-masing kelompok

Diagram rerata kadar MDA plasma pada gambar 1 menunjukkan perbedaan kadar MDA plasma masing-masing kelompok. Kadar MDA plasma tertinggi pada kelompok kontrol positif sebesar 7,7 nmol/ml, sedangkan kadar MDA plasma terendah pada kelompok perlakuan 2 sebesar 2,8 nmol/ml. Uji lanjut Post-hoc LSD dilakukan untuk menganalisis perbedaan rerata kadar MDA plasma antar kelompok, sehingga dapat diketahui kelompok yang berpengaruh menurunkan kadar MDA plasma. Hasil uji lanjut Post-hoc LSD dapat dilihat pada tabel 4 .

Tabel 4. Perbedaan rerata antar kelompok

\begin{tabular}{ccc}
\hline Uji Post-hoc & $\begin{array}{c}\text { Perbedaan } \\
\text { rerata } \\
(\mathbf{n m o l} / \mathbf{m l})\end{array}$ & $\boldsymbol{p}$ \\
\hline $\mathrm{K}^{+}$vs P1 & 1,57 & $0,000^{*}$ \\
$\mathrm{~K}^{+}$vs P2 & 4,85 & $0,000^{*}$ \\
$\mathrm{P} 1$ vs P2 & 3,29 & $0,000^{*}$ \\
\hline
\end{tabular}

Uji Post-hoc LSD *berbeda bermakna $(p<0,05)$

Hasil dari uji lanjut Post-hoc LSD menunjukkan bahwa nilai signifikansi perbedaan rerata antar kelompok sebesar 0,000 $(p<0,05)$, sehingga dapat dijelaskan bahwa terdapat perbedaan yang bermakna rerata kadar MDA plasma antar kelompok. Berdasarkan tabel 4 diketahui perbedaan rerata kadar MDA plasma antara kelompok kontrol positif dan perlakuan 2 sebesar 4,85 $\mathrm{nmol} / \mathrm{ml}$, sedangkan antara kelompok kontrol positif dan perlakuan 1 sebesar 1,57 $\mathrm{nmol} / \mathrm{ml}$, sehingga dapat disimpulkan bahwa kelompok perlakuan 2 signifikan mempengaruhi penurunan kadar MDA plasma. 


\section{PEMBAHASAN}

\section{Kandungan flavonoid dan kuersetin bubuk daun kenikir}

Kandungan flavonoid dan kuersetin bubuk daun kenikir diuji di Laboratorium Ilmu Pangan UNIKA Soegiyapranata Semarang. Berdasarkan hasil yang ditampilkan pada tabel 1, kandungan flavonoid dan kuersetin bubuk daun kenikir per 100 gram masing-masing sebesar 1089,79 $\mathrm{mg}$ dan 390,95 mg. Menurut Andarwulan menyebutkan bahwa dalam 100 gram daun kenikir segar mengandung flavonoid sebesar $143 \mathrm{mg}$ dan kuersetin sebesar 51,3 mg. ${ }^{11}$ Perbedaan ini terjadi karena pembuatan 100 gram bubuk daun kenikir membutuhkan $526 \mathrm{~g}$ daun kenikir segar, sehingga terjadi akumulasi kandungan flavonoid dan kuersetin pada bubuk daun kenikir.

Selain itu, suhu yang digunakan pada proses pengeringan daun kenikir maksimum $50{ }^{\circ} \mathrm{C}$. Menurut Santoso menyatakan bahwa suhu tersebut merupakan suhu optimal pengeringan untuk mencegah hilangnya kadar antioksidan daun kenikir. ${ }^{21}$ Sehingga kandungan flavonoid dan kuersetin bubuk daun kenikir lebih tinggi dibandingkan dengan daun kenikir segar.

\section{Berat badan subjek penelitian}

Penimbangan berat badan subjek dilakukan pada saat sebelum dan sesudah perlakuan. Selama perlakuan juga dilakukan penimbangan berat badan 3 hari sekali untuk menghitung dosis pakan dan perlakuan bubuk kenikir yang diberikan. Hasil analisis pada tabel 2 menunjukkan bahwa terdapat perbedaan yang bermakna antara sebelum dan sesudah perlakuan pada masing-masing kelompok. Kelompok kontrol positif mengalami penurunan berat badan sebesar 13,99\%, sedangkan peningkatan terjadi pada kelompok perlakuan 1 dan perlakuan 2 masing-masing sebesar $11,87 \%$ dan $11,63 \%$. Hal tersebut terjadi karena kelompok kontrol positif mengalami diabetes tanpa diberikan perlakuan.

Menurut American Diabetes Association menyatakan bahwa gejala yang terjadi pada diabetes adalah polyuria, polydipsia, polyphagia, penglihatan kabur dan penurunan berat badan. ${ }^{3}$ Penurunan berat badan terjadi karena jumlah pakan yang diberikan sama pada masing-masing kelompok sebesar 15-20 g, sehingga kondisi rasa lapar yang berlebihan (polyphagia) tidak diimbangi dengan asupan pakan yang diberikan. Selain itu, terjadi glukoneogenesis secara terus menerus pada kondisi diabetes setelah diinduksi streptozotocin sehingga mempengaruhi penurunan berat badan subjek. ${ }^{25}$
Peningkatan berat badan pada kelompok perlakuan 1 dan perlakuan 2 disebabkan perlakuan yang diberikan. Berdasarkan penelitian terdahulu menyatakan bahwa kuersetin mampu menurunkan kadar glukosa darah, mengendalikan stress oksidatif, dan melindungi fungsi sel beta pankreas pada kondisi diabetes. ${ }^{8,9}$ Sehingga kuersetin yang terkandung dalam bubuk daun kenikir dapat menghambat proses glukoneogenesis dan mampu mengendalikan penurunan berat badan pada kelompok perlakuan 1 dan perlakuan 2. Hal tersebut sesuai dengan hasil uji korelasi yang menunjukkan bahwa terdapat korelasi negatif yang bermakna antara berat badan sesudah perlakuan dengan kadar MDA plasma, sehingga dapat disimpulkan semakin rendah berat badan akibat kondisi diabetes berhubungan dengan tingginya kadar MDA plasma. Pengaruh bubuk daun kenikir terhadap kadar MDA plasma

Bubuk daun kenikir diharapkan mampu menurunkan kadar MDA plasma. Rerata kadar MDA plasma sesudah perlakuan menunjukkan perbedaan yang bermakna antar kelompok $(p=0,000)$. Pada tabel 3 menunjukkan bahwa rerata kadar MDA plasma pada kelompok kontrol positif

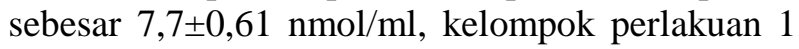
sebesar $6,1 \pm 0,58 \mathrm{nmol} / \mathrm{ml}$ dan kelompok perlakuan 2 sebesar $2,8 \pm 0,50 \mathrm{nmol} / \mathrm{ml}$.

Rerata kadar MDA plasma pada kelompok kontrol positif lebih tinggi daripada kelompok perlakuan 1 dan perlakuan 2. Peningkatan kadar MDA plasma berkaitan dengan stress oksidatif pada kondisi diabetes induksi streptozotocin (STZ). Terdapat beberapa jalur mekanisme peningkatan stress oksidatif akibat hiperglikemia, yaitu jalur poliol, jalur peningkatan produksi Advanced Glycation End products (AGEs), jalur aktivasi protein kinase $\mathrm{C}(P K C)$, dan hexosamine pathway flux.$^{26}$ Peningkatan produksi AGEs mengakibatkan kerusakan sel melalui 3 mekanisme, yaitu autooksidasi glukosa, pembentukan metilglioksal, dan fosforilasi oksidatif yang berakhir pada kerusakan vaskular sehingga kadar MDA plasma meningkat., ${ }^{4,26}$ Menurut Liu dan Adewole menyatakan bahwa tikus diabetes yang diinduksi streptozotocin dapat meningkatkan kadar MDA. ${ }^{6,9}$ Selain itu, penelitian Lienderi pada manusia juga menunjukkan bahwa kadar MDA serum pasien dengan diabetes melitus lebih tinggi dibandingkan pasien tanpa diabetes melitus pada katarak senilis imatur. $^{27}$

Rerata kadar MDA plasma kelompok perlakuan 1 dan perlakuan 2 lebih rendah dibandingkan kelompok kontrol positif. Hal tersebut terjadi karena pada kelompok perlakuan 1 
diberikan bubuk daun kenikir dosis $700 \mathrm{mg}$ mengandung total flavonoid 7,62 mg dan kuersetin 2,74 mg sedangkan kelompok perlakuan 2 diberikan dosis $1400 \mathrm{mg}$ mengandung total flavonoid 15,26 $\mathrm{mg}$ dan kuersetin 5,47 mg. Bubuk daun kenikir mengandung antioksidan nonenzimatik golongan flavonoid yaitu kuersetin. Berdasarkan penelitian sebelumnya, secara in vivo kuersetin dapat menurunkan kadar glukosa darah, melindungi fungsi sel beta pankreas serta menurunkan angka morbiditas dan mortalitas pada tikus model komplikasi vaskular diabetes melalui proteksi membran sel dengan menghambat stress oksidatif. ${ }^{7-}$ ${ }^{9}$ Penelitian Camelia menyatakan bahwa kuersetin murni dosis $5 \mathrm{mg} / 250 \mathrm{gBB} /$ hari selama 28 hari mampu menurunkan kadar MDA serum tikus wistar diabetes diinduksi STZ. ${ }^{28}$ Penelitian lain menunjukkan kuersetin dari ekstrak daun pohon pagoda (Sophora japonica L.) sebesar 4 $\mathrm{mg} / 200 \mathrm{gBB} / \mathrm{hari}$ selama 8 minggu dapat menurunkan kadar MDA pankreas tikus diabetes diinduksi STZ. ${ }^{8}$

Mekanisme kuersetin dalam menurunkan kadar MDA melalui peningkatan antioksidan nonenzimatik (eksogen). Pemberian daun kenikir yang mengandung kuersetin dapat memberikan kompensasi pada antioksidan endogen yang melemah akibat kondisi diabetes. Kuersetin akan menghambat pembentukan radikal bebas dengan menetralisir peningkatan reactive oxygen species (ROS) dan memberikan perlindungan membran sel sehingga peroksidasi lipid dapat dicegah. ${ }^{7,8}$ Keseimbangan yang terbentuk antara antioksidan dan radikal bebas dalam tubuh akan menurunkan kadar MDA. Penurunan kadar MDA berkorelasi positif dengan menurunnya stress oksidatif dan risiko komplikasi vaskular diabetes. ${ }^{9}$

Berdasarkan tabel 4 menunjukkan perbedaan rerata kadar MDA plasma antara kelompok kontrol positif dan perlakuan 2 sebesar $4,85 \mathrm{nmol} / \mathrm{ml}$, sedangkan antara kelompok kontrol positif dan perlakuan 1 hanya sebesar $1,57 \mathrm{nmol} / \mathrm{ml}$, sehingga dapat disimpulkan bahwa kelompok perlakuan 2 efektif mempengaruhi penurunan kadar MDA plasma tikus diabetes diinduksi streptozotocin.

\section{SIMPULAN}

Rerata kadar MDA plasma masing-masing kelompok sebesar $7,7 \mathrm{nmol} / \mathrm{ml}$ pada kelompok kontrol positif, $6,1 \mathrm{nmol} / \mathrm{ml}$ pada kelompok perlakuan 1 dan $2,8 \mathrm{nmol} / \mathrm{ml}$ pada kelompok perlakuan 2. Bubuk daun kenikir sebesar 700 $\mathrm{mg} / 200 \mathrm{gBB} / \mathrm{hari}$ (perlakuan 1) dan 1400 $\mathrm{mg} / 200 \mathrm{~g} /$ hari (perlakuan 2) selama 21 hari mampu menurunkan kadar MDA plasma tikus Wistar diabetes diinduksi streptozotocin $(p<0,05)$.

\section{DAFTAR PUSTAKA}

1. World Health Organization (WHO). Definition and Diagnosis of Diabetes Mellitus and Intermediate Hyperglycemia. 2006:7-11. doi:ISBN 924159493 4.

2. Perkumpulan Endokrinologi Indonesia (PERKENI). Konsensus Pengelolaan dan Pencegahan Diabetes Melitus Tipe 2 di Indonesia 2011. 2011:7-9.

3. American Diabetes Association. Diagnosis and Classification of Diabetes Mellitus. 2008;31(1):5560. doi:10.2337/dc08-S055.

4. Mahreen R, Mohsin M, Nasreen Z. Significantly Increased Levels of Serum Malondialdehyde in Type 2 Diabetic with Myocardial Infarction. Int J Diab Ctries. 2010;30(1):49-51.

5. Rodrigo R, Toro J. Oxidative Stress: Basic Overview. In: Rodrigo R, ed. Oxidative Stress and Antioxidants: Their Role In Human Disease. Vol 1st ed. New York: Nova Science Publisher, Inc; 2009:9-14.

http://medcontent.metapress.com/index/A65RM03 P4874243N.pdf.

6. Liu Wei-hua, Hei Zi-qing, Nie Hong, Tang Fu-tian $\mathrm{HH}$. Berberine ameliorates renal injury in streptozotocin-induced diabetic rats by suppression of both oxidative stress and aldose reductase. Chin Med J. 2008;121(8):706-712. doi:10.1111/j.14631326.2011.01375.x.

7. Gregory S. Kelly N. Quercetin. Altern Med Rev. 2011;16(2):172-194.

8. El-baky AEA. Quercetin Protective Action on Oxidative Stress, Sorbitol, Insulin Risistance and B-Cells Function in Expermintal Diabetic Rats. Int J Pharm Stud Res. 2011;II(2):11-18.

9. Adewole S, Caxton M, JA. O. Protective effect of quercetin on the morphology of pancreatic betacells of streptozotocintreated diabetic rats. Afr J Tradit Complement Altern Med. 2006;4:64-74.

10. Youl E, Bardy G MR. Quercetin potentiates insulin secretion and protects INS-1 pancreatic $\beta$-cells against oxidative damage via the ERK1/2 pathway. J Pharmacol Br. 2010;161:799-814.

11. Andarwulan N, Batari R, Sandrasari DA, Bolling B, Wijaya H. Flavonoid content and antioxidant activity of vegetables from Indonesia. Food Chem. 2010;121(4):1231-1235. doi:10.1016/j.foodchem.2010.01.033.

12. Abdullah A, Dhaliwal KK, Nabillah N, Roslan F, Lee C. The Effects of Cosmos caudatus (Ulam Raja) on Detoxifying Enzymes in Extrahepatic Organs in Mice. J Appl Pharm Sci. 2015;5(01):8288. doi:10.7324/JAPS.2015.50115.

13. Shui G, Leong LP WS. Rapid screening and characterization of antioxidants of Cosmos caudatus using liquid chromatography coupled with mass spectrometry. $J$ Chromatogr $B$. 
2005;827(1):127-138.

doi:10.1016/j.jchromb.2005.07.029.

14. Bunawan H, Baharum S, Siti N, Amin N. Cosmos Caudatus Kunth: A Traditional Medicinal Herb. Glob J Pharmacol. 2014;8(3):420-426. doi:10.5829/idosi.gjp.2014.8.3.8424.

15. Purwaningsih W. Pemberian Suspensi Bubuk Kedelai Dapat Menurunkan Kadar Malondialdehid ( Mda ) Serum Pada Tikus Putih Diabetes. Gaster. 2012;9(2):55-61.

16. Sekar M, Zulhilmi M, Abdullah BIN. Ten Commonly Available Medicinal Plants In Malaysia Used For The Treatment Of Diabetes - A Review. 2014;7(1):1-5.

17. King AJF. The use of animal models in diabetes research. Br J Pharmacol. 2012;166(3):877-894. doi:10.1111/j.1476-5381.2012.01911.x.

18. Nugroho AE. Animal Models of Diabetes Mellitus : Pathology and Mechanism of Some Diabetogenics. Biodiversitas, J Biol Divers. 2006;7(4):378-382. doi:10.13057/biodiv/d070415.

19. Damasceno DC, Netto a. O, Iessi IL, Gallego FQ, Corvino SB, Dallaqua B. Streptozotocin-induced diabetes models: Pathophysiological mechanisms and fetal outcomes. Biomed Res Int. 2014;1:1-11. doi:10.1155/2014/819065.

20. Tomasz S. Streptozotocin-nicotinamide-induced diabetes in the rat. Characteristics of the experimental model. Exp Biol Med. 2012;237(5):481-490. doi:10.1258/ebm.2012.011372.

21. Santoso A. Efek pemberian ekstrak methanol daun kenikir (Cosmos caudatus Kunth.) terhadap kadar asam urat tikus putih galur wistar hiperurisemia [skripsi]. Surakarta: UMS. 2012:1-34.

22. Radman HM, Yusof $\mathrm{K}, \mathrm{Hj} \mathrm{Q}$, Wan Ngah WZ, Abdullah A. The effect of Ulam Raja ( Cosmos caudatus ) on drug- metabolizing enzymes, lipid peroxidation and antioxidant status in mice liver . 2014;6(4):1213-1225.

23. Norazlina M, Ehsan SZ, Noor 'Adilah K, Lee CP, Farhana E, Derick P. Acute toxicity study of Cosmos caudatus on biochemical parameters in male rats. Sains Malaysiana. 2013;42(9):12471251.

24. D, Konig. Berg. Exercise and oxidative stress: is there a need for additional antioxidant osterreichisches. J Fur Sport. 2002;3:6-15.

25. Sharma AK, Richards PA. Diabetic Neuropathy In Various Animal Models. In: Chronic Complications In Diabetes - Animal Models and Chronic Complications. Vol 1st ed. Harwood Academic Publishers; 2005:133-135.

26. Donnelly R. Mechanisms of hyperglycaemia induced vascular dysfuntion. In: Donnelly R, Horton E, eds. Vascular Complications of Diabetes: Current Issue in Pathogenesis and Treatment. Vol 5. 2nd ed. Missouri: Blackwell Publishing; 2005:179-189. doi:10.1136/bmj.320.7241.1062.
27. Lienderi Wati NM. Kadar malondialdehyde serum pasien dengan diabetes melitus lebih tinggi daripada tanpa diabetes melitus pada katarak senilis imatur [Tesis]. Denpasar: UNUD. 2013:1-28.

28. Camelia CI, Baltaru D, Maier M, Mureşan A. Effects of Quercetin and Chronic (Training) Exercise on Oxidative Stress Status in Animals with Streptozotocin-Induced Diabetes. Bul UASVM, Vet Med. 2013;70(1):31-39. 